Agro-Science Journal of Tropical Agriculture, Food, Environment and Extension Volume 18 Number 2 (May 2019) pp. 32-36

ISSN 1119-7455

\title{
EFFECTS OF AVIAN FLU ON THE CONSUMPTION OF CHICKENAND EGG AMONG UNIVERSITY OF ILORIN STAFF, ILORIN, NIGERIA
}

\author{
Belewu K.Y. \\ Department of Agricultural Economics and Farm Management, \\ University of Ilorin, Ilorin, Nigeria \\ Correspondent author $\varepsilon$-mail:- belyem9@gmail.com
}

\begin{abstract}
The dissemination and maintenance of AIV in wild birds is important for understanding the factors that contribute to transmission of AIV from wild birds to poultry. This study examined the impact of Avian flu on the consumption of chicken and egg among university of Ilorin staff, in Ilorin, Kwara state, Nigeria. A survey was conducted by interviewing 110 University of Ilorin staff. Information was collected on the same economic characteristics of the respondents, income and consumption of chicken and eggs. The data were analyzed using descriptive statistics. The results revealed that Avian flu outbreaks and spread in Nigeria have caused serious threat to the poultry industry, the food security and livelihoods of urban communities. It was also noted that there was a decline in consumers' confidence in poultry product (e.g chicken and egg) as indicated by the respondents. Perception of people about avian flu pandemic indicates $90 \%$ of respondents perceived it as deadly, incurable and easily transmissible disease and that was why $77.27 \%$ of the sampled households were found to have stopped or drastically reduced the consumption of poultry products for the fear of being infected by the disease. The research conclude that since most of people perceived avian influenza as deadly disease, government enact measures to prevent the virus from spreading and to reduce the risk of infection and ban on transporting poultry in the area where bird flu has occurred.
\end{abstract}

Key words: avian virus, wild birds, domestic poultry, egg, chicken.

\section{INTRODUCTION}

Livestock sub-sector of the agricultural sector of which poultry production is a component provides animal protein for the people (FMANR, 2001). Weeks \& Nicol (2006) noted that Chicken meat and eggs are the best source of quality protein, and are badly needed by the many millions of people who live in poverty in many African countries. Poultry comprises of chicken, turkeys, ducks, quails, pheasant, fowls, guinea fowl, pigeon etc. Eggs and meat of birds have been consumed since pre-historic times. There are many diseases that affect poultry in general and chicken in particular. These include bacterial, fungal and viral diseases. (Badmus, 2006).Among the viral diseases of poultry is the Avian influenza. Avian Influenza Viruses (AIVs) in wild birds have recently received increased attention due to the emergence of the Highly Pathogenic AIV H5N1 strain and its potential threat to human health (Capua \&Alexander 2002). Although numerous studies of low pathogenic AIV strains (LPAI) in waterfowl and wild birds have been published, encompassing tens of thousands of sampled wild birds, The extent to which individual variation in susceptibility to infection, previous infections, and behavioral changes in response to infection determine AIV epidemiology is little understood (Marcel et al. 2011). The avian community in a single ecosystem can include hundreds of interacting species (Shuo et al2015 ). In addition, the response of bird species to specific AIV subtypes (16 hemagglutinins and 9 neuramidases known) is variable and prevalence patterns of specific subtypes is determined by the bird cenosis (Martins, 2012). So far, most studies of AIV have concentrated on anseriforms and to a lesser extent on charadriiforms, which are known to be reservoirs for LPAI (Olsen et al., 2006) . In their synthesis of wild bird low pathogenic avian influenza surveillance worldwide, Olsen et al.(2006) found that out of more than 90000 birds sampled, $54 \%$ were anseriforms and $25 \%$ charadriiforms. 
As a consequence, little information on AIV prevalence in the rest of the avian community has been published, and much of what has been published has been obtained as "by-catch" from capture protocols that have been focused on ducks (Martins 2012). The minimum sample sizes that would be necessary to confidently estimate prevalence for most non-target bird species are often not reached, with the risk that the common practice of focusing mainly on anseriforms may be overlooking the role of other bird groups in the epidemiology of AIV in waterfowl communities (WHO, 2004). The broad objective of this work was to determine the effect of Avian flu on the consumption of chicken and egg. The specific objectives include; assessing the awareness of consumers on Avian flu pandemic, determination of consumers' perception of the disease vis-a-vis its health effects and to analyze the effects of the disease on the consumption of chicken and egg in the study area.

\section{Economic Implications}

Highly pathogenic avian influenza (HPAI) virus of the H5N1 subtype is a disease that has devastating effect on the poultry industry. So far, over 3.7 million birds have been culled and over 4million birds exposed in the current resurgence of the virus in Nigeria which was officially confirmed in the country on the 2nd of January, 2015 (Ayi et al., 2017). The direct economic losses in the current HPAI H5NI resurgence is much more than the previous outbreaks that occurred from 2006 to 2008 in the country and the percentage of birds that were exposed to the total poultry population have more than doubled that of the previous outbreak (2006-2008). This is an indication that more jobs have been lost, more loss in production and its attendant effect on businesses that are related to poultry production in the country such as veterinary health care services, the poultry feed industries and restaurants (Wang, 2017).

\section{MATERIALS AND METHODS}

\section{Study Sites}

The study area is the University of Ilorin, Ilorin. The university is located in the ancient city of Ilorin about $500 \mathrm{~km}$ from Abuja, the Federal capital of Nigeria. Ilorin the capital of Kwara State is strategically located in the geographical and cultural confluence of the North and the South. The latitude of Ilorin, is 8.500000 , and the longitude is 4.550000. Ilorin, is located at Nigeria country in the Cities place category with the gps coordinates of $8^{\circ} 30^{\prime} 0.0000^{\prime \prime} \mathrm{N}$ and $4^{\circ} 32^{\prime} 60.0000^{\prime \prime}$ E. Ilorin, elevation is 310 meters height, that is equal to 1,017 feet. The University is one of the seven institutions of higher learning established by the Federal Government of Nigeria in August, 1975.

\section{Sample Design}

The population for this study consists of the staff of University of Ilorin, Ilorin, Kwara State. A twostage sampling technique was employed to select senior staff in the University. The first stage involved the purposive selection of University of Ilorin, because almost all of them were able to avoid purchasing chicken and poultry products. The second stage involved random selection of senior staff both male and female. A total of 27 female and 83 male were collected making total of 110 staff.

\section{Data Collection}

Primary data were used for the study. The primary data were sourced using a structured questionnaire administered by interviewing the senior staff both male and female. Information on their socioeconomic characteristics (age, family size and educational status, other source of income) were collected.

\section{Method of Data Analysis}

Descriptive statistics and descriptive valuation were used to achieve the objectives of this study. This involves percentage, frequencies, mean, and mode.

\section{Limitations to the Study}

Since the respondents were educated, the questionnaire was given to them, there was delayed in returning the questionnaire and not all were retrieved. The initial total questionnaire was 130, but I gathered 110 which I analyzed.

\section{RESULTS AND DISCUSSION}

Table 1 reveals that $(75.46 \%)$ of the respondents were males, while $(24.54 \%)$ were females. This implies that majority of the respondent males are bread winners in their houses while the females were also interviewed. The age of an individual is an important factor which determines food consumption level, because majority of the respondents are $\mathrm{Ph} . \mathrm{D}$ holders and are of middle age of between 31 and 50 years $(68.18 \%)$ ). It is within this range that average income of the respondents is expected to be high. The level of income determines the level of food consumption especially poultry meat and products as studied in this research. It also revealed that majority of the respondents $72.73 \%$ were married.

The number of household (family size) influence consumption pattern as above $45 \%$ have family size between 6-10 which support the findings of (Enstone et al., 2009). Also as the size of the household increases at a particular level of income, the total disposable income that is spent, on food consumption will definitely increase and this reduces the total amount saved by the households (FAO, 2004). 
Belewu K.Y.

Table 1: Socio-Demographic Variables

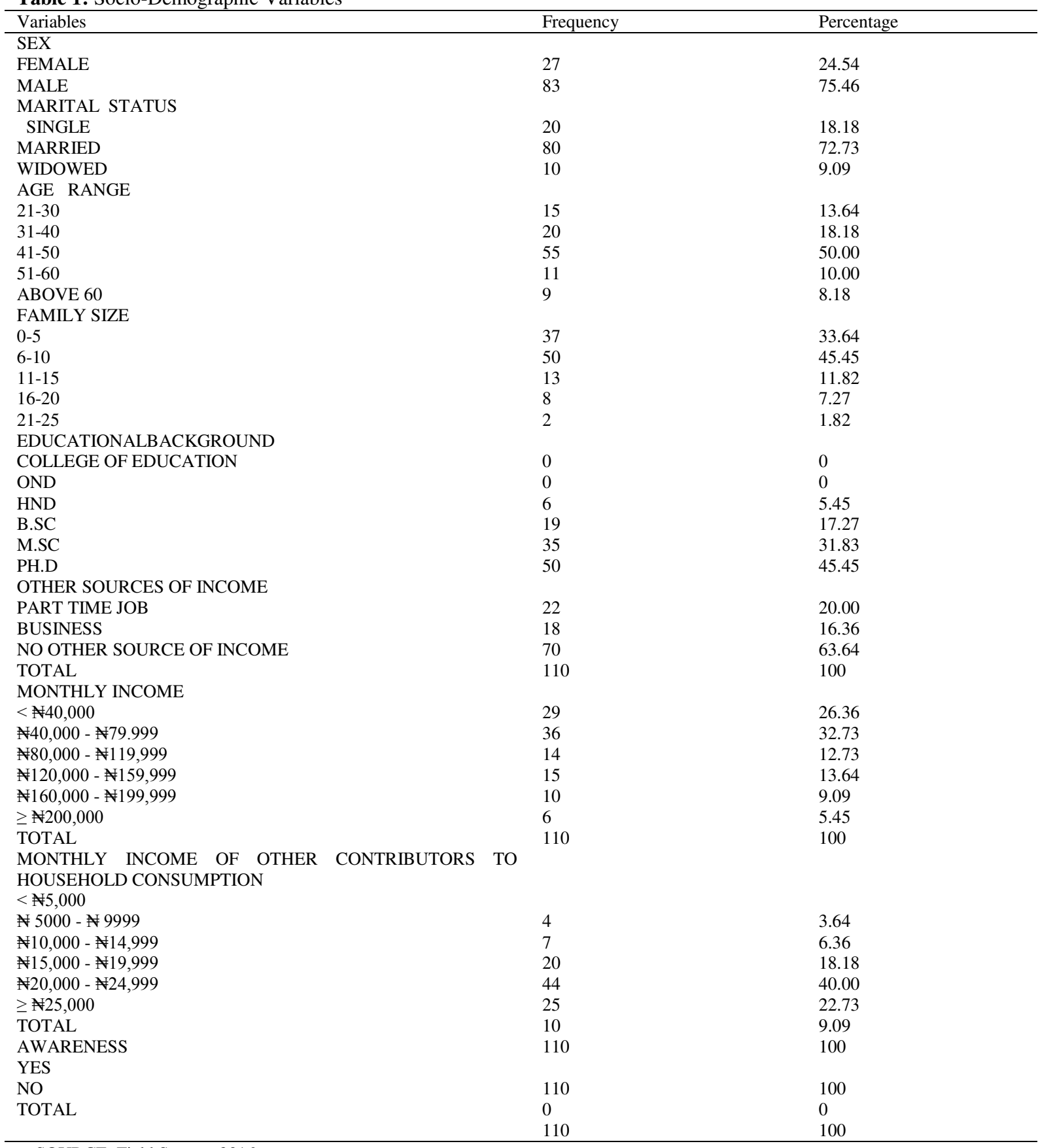

- SOURCE: Field Survey, 2016

Table 2: Distribution of Respondents According to Influence of Avian flu Chicken Consumption

\begin{tabular}{lll}
\hline Effect on consumption & Frequency & Percentage \\
\hline Yes & 85 & 77.27 \\
No & 25 & 22.73 \\
Total & 110 & 100 \\
Willingness to Pay for a Safe Poultry & & \\
Products. & 93 & 66.36 \\
Yes & 37 & 33.64 \\
No & 110 & 100 \\
Total & & \\
Substituting other Protein Sources for & & \\
Chicken & 25 & 22.73 \\
Beef & 20 & 18.18 \\
Fish & 60 & 59.09 \\
No substitution & 110 & 100 \\
Total & & \\
\hline Source: Field Survey, 2016 &
\end{tabular}

Source: Field Survey, 2016 
Hence, majority of the respondents $(45.45 \%)$ are most educated (Ph.D) and this is expected to influence their consumption pattern. This set of elite will always like to take good quality food even if it is costly. Therefore the consumption of poultry products is common among the literate people because they know the importance of protein which support the findings of Sparks (2006). However, the other sources of income of respondents' i.e. part time Salary job and business occupied $(36.36 \%)$, but majority of respondents do not have other sources of income $(63.64 \%)$. The monthly income of respondents; about $33 \%$ of respondents have $\$ 40000$ to $\$ 79999$. Previous studies have shown that income determines the level of consumption of household (FAO, 2004). This has positive influence on the consumption patterns of the respondents. The higher the income earned, the higher the level of consumption (FDA, 2010). Again from Table 1, the monthly income of other contributors (apart from bread winners) to household consumption. Major contribution ranges from $\$ 10,000$ - 24,999 with $(80.91 \%)$. Due to the higher income, they can afford to consume more of the poultry products. Social Cultural factors like religion, belief, food preferences, gender, discrimination and education; all these have been observed to have influence on Avian chicken consumption pattern (Driskell et al 2010). Also table 1 below indicated that all respondents were aware of avian flu pandemic in one way or the other. Majority are aware through the media like Television, Radio, internet, Newspaper, Colleagues, Neighbors, Seminar, Conference, etc.

Table 2 shows the influence of avian flu on chicken consumption. Majority of the respondents $(77.27 \%)$ declared that the disease has affected their chicken consumption even including all other poultry products. Globally, evidence demonstrated that there is no risk of infection when birds and eggs are well cooked as this kills the virus (WHO, 2006).

This assertion was confirmed by only $22.73 \%$ who believed that thorough cooking of poultry products will get rid of avian flu. Hence the outbreak of the virus did not influence their consumption of poultry products. However, majority of the respondents are willing to pay more for safer poultry products (i.e. cost of preventing the outbreak of disease) by doing thorough cooking of poultry products and take proper precaution when keeping poultry. Most of the people believed that prevention is better than cure that is why $(66.36 \%)$ of the respondents are ready to pay for safer poultry products while $33.64 \%$ do not want to pay anything for the safety. Table 2 also revealed that all most $41 \%$ of respondents substitute for chicken and poultry product during the avian flu pandemic. About 59.09\% of the respondents did not substitute chicken and egg with anything.

\section{Perceptions of Respondents on Avian Flu Pandemic}

Majority of respondents perceived avian flu as deadly, incurable disease and easily transmissible disease and that was why $(77.27 \%)$ of the respondents refused to consume poultry product during this study (as shown in table 5). This observation confirmed the report that there was a period of quiescence of HPAI H5N1 outbreak in Africa from 2009 through to 2013, Egypt has been declared as a country endemic to HPAI H5N1, due to the number of confirmed human cases and recorded deaths emanating from these outbreaks (OIE, 2014).The observation in this study also supports, the report that In West Africa, outbreaks and reinfections were however confirmed in Côte d'Ivoire, Ghana, Niger, Nigeria, and Burkina Faso. (Fasanmi et al., 2016).

\section{CONCLUSION}

It could conclude that since most of people perceived avian influenza as deadly disease, government could enact measures to prevent the virus from spreading and to reduce the risk of infection and ban on transporting poultry in the area where bird flu has occurred.

\section{RECOMMENDATION}

Furthermore, there is need to implement government plans on ground such as intensive biosecurity and strict movement control in order to curtail the current outbreaks and possible elimination of the disease from the country. There is need for timely payment of compensation to the farmers to encourage effective disease reporting by affected farmers and also reduce the spread of the disease to other farms. A key policy question for Nigeria government and other countries on bird flu outbreak is how to win the trust and confidence of the population consuming poultry, minimize panic and disruption and indeed mobilize the public as a key partner in eradicating the disease. Attention to the avian flu disease in Nigeria calls for serious concern for human health as well as for agricultural sector (especially the poultry industry that is in crisis).Nigeria government policy of culling affected birds has the potential danger of wiping out smaller and power farmers in Nigeria, which could further aggravate the social distortions now occurring in the economy and the agricultural sector. Rapid elimination of the H5N1 virus in bird population should be given high priority as a matter of international public health importance.

\section{ACKNOWLEDGEMENTS}

I gratefully thank Prof. M.A.Y RHAJI (Department of Agricultural Economics, University of Ibadan, Ibadan), for supervising this work. 


\section{REFERENCES}

AyiVandi K., Columba T., Vakuru M., Dika N., Salome Y., Tafida M., Kachalla B., Ewa E., Zainab A., Gideon M., Mshe 1., Gidado M., Madaki. and Adamu A. EL-Oji (2017). Economic Losses and Implications of Highly Pathogenic Avian Influenza (HPAI) H5N1 Resurgence in Nigeria. International Journal of Scientific \& Engineering Research, 8 (9), September-2017 ISSN 2229-5518 IJSER

Badmus O. (2006). "Bird flu a sabotage" The punch Newspaper, February 15, 2006 pg 42. Capua I, and Alexander DJ (2002): Avian influenza and human health. Acta Trop., 83, 1-6.

Driskell E.A, Jones C.A, Stallknecht DE, Howerth EW, Tompkins SM (2010). Avian influenza virus isolates from wild birds replicate and cause disease in a mouse model of infection. Virology, 399 (2), 280289

Enstone J.E, Myles P.R., Openshaw P.J.M., Gadd E.M., Lim W.S. and Semple M.S. (2011). Nosocomial pandemic (H1N1) United Kingdom, 2009-2010. Emerging Infectious Diseases; 17 (4), 592-8

FAO Fact Sheet (2004). "Market impact of Avian flu in Asia, Rome 2004"

Fasanmi O.G, Laleye A.T. and Fasina F.O. (2016). Systematic review and meta-analyses of cases and deaths associated with HPAI H5N1 in humans and poultry. CAB Rev. Perspect. Agric. Vet. Sci. Nutr. Nat. Resour., 11:4

FDA - US Food and Drug Administration (2010). Medical devices and flu emergencies 2010 [cited 2012 April 06]. Available from: http://www. fda.gov/MedicalDevices/Safety/EmergencySituation s/ucm161496.htm

FMANR (2001). Nigerian National Agricultural Research plan (1996-2001) Dept of Agric Sciences, Federal Ministry of Agriculture and National Resources, Abuja
Marcel Klaassen Bethany J. Hoye and David A. Roshier (2011). Identifying crucial gaps in our knowledge of the life-history of avian influenza viruses-an Australian perspective. Emu-Austral Ornithology, 111:2, 103-112, DOI: 10.1071/MU10042

Martins N.R da S. (2012). "An Overview on Avian Influenza" Brazilian Journal of Poultry Science ISSN 1516-635X Apr - Jun 2012/ v.14 / n.2 /71-158

OIE World Organisation for Animal Health. (2017) Highly Pathogenic Avian Influenza, Technical Disease Card. 2014. [Accessed on 24-022017]. Available from: http://www.oie.int .

Olsen B Munster V.J, Wallensten A., Waldenstrom J., Osterhaus A.D. and Fouchier R.A. (2006). Global patterns of influenza a virus in wild birds. Science, 312, 384-388

Shuo S.u., Yuhai Bi., Gary W., Gregory C., Gray George F. Gao. and Shoujun L.I. (2015). Epidemiology, evolution, and recent outbreaks of Avian Influenza virus in China. Journal of Virology, 89 (17), 86718676; DOI: $10.1128 /$ JVI.01034-15

Sparks N.H.C. (2006). The hen's egg - is its role in human nutrition changing? World's Poultry Science Journal, 62 (2), 308-315.

Wang SF. (2017). Brief introduction of emerging avian influenza a virus. J Clin. Microbiol. Infect. Dis., 1 (1)

Weeks C.A. and Nicol C.J. (2006). Preferences of laying hens. World's Poultry Science Journal, 62, 296-307

WHO (2004). Avian Influenza H5N1 infection in humans: Urgent need to eliminate the animal reservoir. Update 5.EPR January 22. http://www.who-int/csr/don/2004-0122lenlindex.html.

WHO (2006). Avian Influenza - situation in Nigeria update 2. EPR March 92006. 